\title{
EquiLIBRIUM
}

Quarterly Journal of Economics and Economic Policy

2016 VOLUME 11 ISSUE 1, March

p-ISSN 1689-765X, e-ISSN 2353-3293

www.economic-policy.pl

Kordalska, A., \& Olczyk, M. (2016). Global Competitiveness and Economic Growth: A One-Way or Two-Way Relationship?. Equilibrium. Quarterly Journal of Economics and Economic Policy, 11(1), pp. 121-142, DOI: http://dx.doi.org/10.12775/ EQUIL.2016.006

\author{
Aleksandra Kordalska, Magdalena Olczyk ${ }^{*}$ \\ Gdansk University of Technology, Poland
}

\section{Global Competitiveness and Economic Growth: A One-Way or Two-Way Relationship?}

JEL Classification: $O 40$; $O 57 ; C 23 ; F 43$

Keywords: Global Competitiveness Index; economic growth; panel Granger causality test

\begin{abstract}
The Global Competitiveness Index is treated as a standard to measure the competitiveness of countries. Leaders look at it to make policy and resource allocation decisions, because global competitiveness is expected to be related to economic growth. However, studies which analyze the empirical relationship between these two economic categories are very rare. It is still an open question in the literature whether economic growth can be used to predict future global competitiveness or the other way round. This paper empirically tests the relationship between the GCI and the economic growth rate by using a panel Granger causality analysis based on annual data for 114 countries divided into five groups by income criteria and covering the period 2006-2014. We confirm a strong unidirectional causality among the countries analyzed, i.e. GDP growth causes global competitiveness. Additionally, we find that the GCI is successful in predicting economic growth for the majority low income and OCED high income counties, but among the middle income countries this relationship exists only for large economies such as China and India.
\end{abstract} Toruń

(C) Copyright Institute of Economic Research \& Polish Economic Society Branch in

Date of submission: March 29, 2015; date of acceptance: September 27, 2015

* Contact: Aleksandra.Kordalska@zie.pg.gda.pl; Magdalena.Olczyk@zie.pg.gda.pl, Gdansk University of Technology, Faculty of Management and Economics, ul. Traugutta 79, 80-233 Gdansk, Poland 


\section{Introduction}

National competitiveness is one of the most central preoccupations for both advanced and developing countries (Porter, 1990) and "many policy makers express serious concerns about it" (Lall, 2001, p. 1501). Much has already been written about competitiveness, and today many economic phenomena are described as competitive or non-competitive issues. Nevertheless, both the definition and the analysis of the competitiveness of an economy still pose many problems. First of all, one may be surprised not only by the multitude of definitions of national competitiveness, but also by the diversity of approaches to determining what competitiveness actually is at the macro level. Even such an expert as M. Porter in his book "The competitiveness advantage of nations" does not define it explicitly, despite using the term very often (Olczyk, 2008). Berger identifies four main, but very different, theoretical constructs for national competitiveness, and they show large divergences. National competitiveness can be understood as the "ability of a nation to sell its goods to another nation", as the "ability of a nation to earn", as the "ability to adjust to changes in the external environment" and as the "national ability to attract scarce mobile resources" (Berger, 2008, pp. 378-392). Each approach implies the use of different indicators to assess country competitiveness.

According to Berger, there is a fifth concept of national competitiveness, based on Porter's diamond model and its extended versions. Porter proposed a national diamond model, which identifies four classes of country attributes that determine national competitive advantage: factor conditions; demand conditions; related and supporting industries; and company strategy, structure and rivalry. He also indicates two other factors - government policy and chance (exogenous shocks) - that support the system of national competiveness but do not create it (Porter, 1990). A key feature of Porter's proposal is that it integrates many different theories into the one concept, i.e. "factor conditions" relate to classical/neoclassical economics, "demand conditions" are connected to product cycle theory and Rostow growth theory, "related and supporting companies" derives from polarization theory and Marshall's industrial districts, and "firm strategy, structure and rivalry" refer to Schumpeter's works. Although the diamond model has been widely applied to studying the competitiveness of different countries, it has met with some criticism. According to Smit (2010, pp. 105-130), the weak aspects of Porter's model have been pointed out both by scholars of management (Dunning, 1992; Dunning, 1993; Rugman, 1990; Rugman, 1991; Rugman and Verbeke, 1993) and economics (Waverman, 1995; Boltho, 1996; Davies \& Ellis, 2000). Management experts accuse Porter of 
not considering multinational activities in his model, so Dunning (1993) extended Porter's original model by adding the following variables: foreign direct investment, government policies and pro-competitive policies. In turn, economists indicate a lack of ex ante prediction ability as a weak point of the model.

Nevertheless, the national diamond model was a breakthrough in the study of country competitiveness due to Porter and his followers' complex approach to macro-competitiveness analysis. It opened a discussion about the determinants and indicators of national competitiveness and became a basis for the creation of two leading indices of country competitiveness: that published in the World Economic Forum Report and that in the IMD's World Competitiveness Yearbook. In particular, the methodology used by the World Economic Forum (WEF) is very closely related to Porter's diamond model. It defines country competitiveness as the "set of institutions, policies, and factors that determine the level of productivity of a country" (Schwab, 2015, p. 4). Porter also states that competitiveness has a set of microeconomic determinants (like, e.g., firm strategies, rivalry), macroeconomic conditions (like, e.g., demand) and factors determining government power. Thus, the methodology proposed by the WEF is based on the assumption that competitiveness is such a multidimensional phenomena that the most appropriate approach to assessing country competitiveness as a single indicator involves a compilation of many individual competitiveness indicators.

The WEF constructs a Growth Competitiveness Index (GCI), which includes a weighted average of 112 different components. These components are grouped into 12 pillars of competitiveness and each of them measures a different aspect of it. They are: (1) institutions, (2) infrastructure, (3) macroeconomic environment, (4) health and primary education, (5) higher education and training, (6) goods market efficiency, (7) labour market efficiency, (8) financial market development, (9) technological readiness, (10) market size, (11) business sophistication, and (12) innovation (Global Competitiveness Report 2015-2014, pp. 4-8). These 12 pillars are organized into three groups: basic requirements (pillars 1-4), efficiency enhancers (pillars 5-10) and innovation and sophistication factors (pillars 11-12). The WEF puts a different weight on each of the three groups and divides countries according to their stage of development, because developing countries are competitive in the field of basic requirements, the competitiveness of emerging countries is based on the efficiency enhancers, and at least most developed countries compete thanks to their innovations.

Although the GCI is one of the most accepted and recognized indicators of national competitiveness in the literature, it is not exempt from criticism. 
Lall (2001, pp. 1501-1525) indicates many methodological, quantitative and analytical problems, and dubs the index "misleading" due to its arbitrary weighting of variables and the use of subjective indicators. Other researchers also question the high correlation among its pillars (Carvalho et al., 2012, pp. 421-434), the lack of a good theoretical basis for the selection of its variables (Berger \& Bristow, 2009, pp. 378-392), and even methodological errors and data manipulation which may lead to undesirable results (Freudenberg, 2003, pp. 1-29). Van Stel indicates two of the most serious problems with the GCI (Van Stel et al., 2005, pp. 311-321): the index is not even stable over short time periods for developed economies (the USA was ranked 6th in 2007 and 1st in 2008); and it is not successful in predicting short- and long-term economic growth because it combines so many other variables, such as entrepreneurial activity (Xia et al., p. 47). However, the authors of the latest Global Competitiveness Report state that "the concept of competitiveness thus involves static and dynamic competitiveness and .... can explain an economy's growth potential" (Schwab, 2015, p. 4). Because studies which evaluate the validity of the GCI for economic growth prediction are very rare, the aim of this paper consists in empirically evaluating the effect of global competitiveness on economic growth. In addition, we have decided to go further and check the predictive validity of the inverse relationship, i.e. whether economic growth predicts global competitiveness.

The paper is organized as follows. The next section contains a theoretical discussion on the possible impact of global competitiveness on economic growth and vice versa. Section 3 opens up the methodological part of the paper, i.e. it introduces the data and the panel Granger causality test methodology. Section 4 presents the results of the analysis and the last section gives our conclusions.

\section{Economic Growth Driven by the Global Competitiveness Index or Vice Versa - Theoretical Aspects}

As mentioned, the WEF-constructed Growth Competitiveness Index (GCI) includes a weighted average of 112 different components grouped into 12 pillars of competitiveness, and the pillars are classified into three components: "factors", which determine a better environment for high productivity (Bai, 2009, pp. 257-275), "efficiency", which is connected with the labour, goods and services markets and their influence on production efficiency (Qin et al., 2009, pp. 291-315), and "innovations", which are necessary for growth sustainability (Koong et al., 2011, pp. 181-196). In reality, the majority of 
these pillars are taken from six main economic theories: classical, neoclassical and Keynesian economic theory, development economics, new trade theory, and the most important new economic growth theory - endogenous growth theory (see Table 1). Since the GCI measures "the level of productivity of an economy, which determines its long-term growth potential" (Schwab, 2015, Appendix A), endogenous growth theory becomes more significant.

Table 1. Keys driving factors of competitiveness in main economic theories

\begin{tabular}{|c|c|}
\hline Theory & Keys driving factors of competitiveness \\
\hline Classical & $\begin{array}{l}\text { investment in capital (i.e. improved technology) enhances the } \\
\text { division of labour (specialization) and, hence, raises productivi- } \\
\text { ty. } \\
\text { - } \\
\text { trade (moving from autarky to free trade) provides an engine } \\
\text { for growth (static gains from trade). }\end{array}$ \\
\hline Neoclassical & $\begin{array}{l}\text { - trade (moving from autarky to free trade) provides an engine } \\
\text { for growth (static gains from trade). }\end{array}$ \\
\hline $\begin{array}{l}\text { Keynesian economic } \\
\text { theory }\end{array}$ & $\begin{array}{l}\text { - } \text { capital intensity. } \\
\text { - investment . } \\
\text { - } \text { government spending, such as investment in the public domain } \\
\text { and subsidies/tax cuts for enterprises. }\end{array}$ \\
\hline $\begin{array}{l}\text { Development } \\
\text { economics }\end{array}$ & $\begin{array}{l}\text { - } \text { moving from agriculture to higher value added sectors. } \\
\text { - } \text { openness to trade. } \\
\text { - } \text { foreign direct investment (FDI). } \\
-\quad \text { (foreign) development funds. }\end{array}$ \\
\hline $\begin{array}{l}\text { New economic } \\
\text { growth theory }\end{array}$ & $\begin{array}{l}\text { - } \text { R\&D expenditure. } \\
-\quad \text { innovativeness (patents). } \\
-\quad \text { education level . } \\
-\quad \text { spending on investment in human capital (schooling, training). } \\
-\quad \text { effective dissemination of knowledge (knowledge centres). }\end{array}$ \\
\hline New trade theory & $\begin{array}{l}\text { - } \text { Factors influencing "first mover" advantage, e.g. } \\
\text { - } \text { skilled labour } \\
\text { - } \\
\text { - } \\
\text { - } \\
\text { netwocialized infrastructure } \\
\text { localized technologies }\end{array}$ \\
\hline
\end{tabular}

Source: own elaboration based on (Garden \&Martin, 2005, pp. 10-16).

Endogenous growth is long-run economic growth at a rate determined by forces that are internal to the economic system, and particularly those forces governing the opportunities and incentives to create technological knowledge. This theory attempts to explain the sources of productivity 
growth and emphasizes the crucial roles of human capital (Lucas 1998), innovations (Romer, 1990; Aghion \& Howitt, 1992), infrastructure (Barro, 1990), institutions (Romer, 1986), competition and openness (Grosmman \& Helpman, 1991). In Table 2, the determinants of selected endogenous growth models are assigned to some of the pillars of the GCI.

Table 2. The inspiration for the pillars of global competitiveness from models of endogenous growth

\begin{tabular}{|c|c|c|c|}
\hline $\begin{array}{l}\text { Pillars of } \\
\text { competitiveness }\end{array}$ & Pillar 1 & Pillar 2 & Pillars \\
\hline $\begin{array}{l}\text { Endogenous } \\
\text { growth model } \\
\text { inspirations }\end{array}$ & $\begin{array}{l}\text { Romer (1986): } \\
\text { institutions } \\
\text { Barro (1990): infra- } \\
\text { structure } \\
\text { Lucas (1988): health } \\
\text { and primary educa- } \\
\text { tion }\end{array}$ & $\begin{array}{l}\text { Lucas (1988): health and } \\
\text { primary education } \\
\text { Pagano (1993): sophisti- } \\
\text { cation of financial mar- } \\
\text { kets } \\
\text { Grosmman and Helpman } \\
\text { (1991): opening to tech- } \\
\text { nology and size of the } \\
\text { market }\end{array}$ & $\begin{array}{l}\text { Romer (1990) and } \\
\text { Aghion et Howitt } \\
\text { (1992): sophistica- } \\
\text { tion of firms and } \\
\text { innovations }\end{array}$ \\
\hline
\end{tabular}

Source: Ben Amar \& Hamdi (2012, p. 126).

Because the determinants of growth in endogenous growth theory are often simultaneously key drivers in the GCI pillars, we decided to check the following hypothesis: the GDP growth rate can predict the Global Competitiveness Index.

We also decided to verify the opposite hypothesis: that the GCI can be a good predictor of GDP growth. The authors of older versions of the Global Competitiveness Report themselves claimed that the GCI can "determine the aggregate growth rates of an economy" (Lopez-Claros et al., 2007, p. 3). In the latest WEF Report on Global Competitiveness we can also find the argument that "a more competitive economy is one that likely grows faster over time" (Schwab, 2015, p. 4).

\section{Data and Research Method}

The empirical analysis presented in this paper is based on the Global Competitiveness Index Historical Dataset for 114 countries over the years 20052014. The historical data in the dataset are not updated, but correspond to the data that was originally published in nine past editions of the WEF 
Global Competitiveness Report ${ }^{1}$. The list of countries analysed is limited from 144 to 114 due to either a lack of a Global Competitiveness Index or of GDP PPP values for some countries in part of the period analysed.

We use two variables: the Global Competitiveness Index (GCI) and the GDP PPP annual growth rate. GDP PPP is gross domestic product converted to international dollars using purchasing power parity rates ${ }^{2}$. GDP is the sum of gross value added by all resident producers in the economy plus any product taxes and minus any subsidies not included in the value of the products (World Bank, 2015). An international dollar has the same purchasing power over GDP as the U.S. dollar has in the United States. The data are in current international dollars. For most economies, the PPP figures are either extrapolated from the 2011 International Comparison Program (ICP) benchmark estimates or else imputed using a statistical model based on the 2011 ICP report ${ }^{3}$.

The GCI is a composite competitiveness index combining "hard data" on various national characteristics and "soft data" compiled from the WEF's annual Executive Opinion Survey. To ease the calculation of indexes, the WEF converts all hard data items onto a 1-7 scale using a min-max transformation ${ }^{4}$. The theoretical maximum of GCI is 7. Computation of it is based on successive aggregations of scores from the indicator level. At the most disaggregated level, an arithmetic mean within a category is used to aggregate the individual indicators, while for the higher aggregation levels fixed weights for each category are applied (Schwab, 2015, Appendix B). At the highest aggregation level - i.e. at the three sub-indices level - the weights applied are not fixed and depend on each country's stage of development.

To analyze the relationship between global competitiveness and the economic growth rate, we decided to divide all 114 economies into homogenous groups according to their gross national income (GNI) per capita

1 editions: 2006-2007, 2007-2008, 2008-2009, 2009-2010, 2010-2011, 2011-2012, 2012-2013, 2013-2014, 2014-215

${ }^{2}$ The Purchasing Power Parity (PPP) between two countries is the rate at which the currency of one country needs to be converted into that of the second country to ensure that a given amount of the first country's currency will purchase the same volume of goods and services in the second country as it does in the first.

${ }^{3}$ The International Comparisons Program (ICP) is a global statistical initiative that produces internationally comparable Purchasing Power Parity (PPP) estimates. See http://siteresources.worldbank.org/ICPEXT/Resources/ICP_2011.html.

${ }^{4}$ min-max formula $=6 \cdot \frac{\text { country value }- \text { sample minimum }}{\text { sample maximum }- \text { sample minimum }}+1$

${ }^{5}$ As of 1 July 2014, low-income economies are defined as those with a GNI per capita, calculated using the World Bank Atlas method, of $\$ 1,045$ or less in 2013; middle-income 
calculated using the World Bank Atlas method ${ }^{6}$. The purpose of the Atlas conversion is to reduce the impact of exchange rate fluctuations in the cross-country comparison of national incomes. Each of the economies analysed belongs to one of five groups: low-income, lower-middle-income, upper-middle-income, high-income non-OECD countries, and high-income OECD countries.

In this paper, the relationship described above is assessed by means of a Granger causality test. In accordance with Granger (1969), causality means that a series $x$ can be said to cause a series $y$ if and only if the expectation of $y$ given the history of $x$ differs from the unconditional expectation of $y$ :

$$
E\left(y \mid y_{y-k}, x_{t-k}\right) \neq E\left(y \mid y_{t-k}\right) \text {. }
$$

The question is whether lagged values of series $x$ bring additional information to predict series $y$ or if series $y$ can be better predicted only using its past values.

For $T$ periods and $N$ individuals, the time-stationary VAR model adapted to a panel data context is as follows:

$$
y_{i, t}=\sum_{k=1}^{p} \gamma^{(k)} y_{i, t-k}+\sum_{k=0}^{p} \beta_{i}^{(k)} x_{i, t-k}+v_{i, t}, \quad i=1, \ldots, N, \quad t=1, \ldots, T,
$$

where $v_{i t}$ is the sum of individual effects $\alpha_{i}$ and random disturbances $\varepsilon_{i t}$.

The concept of Granger causality for panel data can be considered in two ways. The first approach, proposed by Holtz-Eakin et al. (1985, p. 12), uses Chamberlain's investigation (1984, pp. 1247-1318) and allows all of the parameters in regression two to be time-varying. Following this, Hsiao (1989, pp. 565-587) and in a similar way Weinhold (1996, pp. 163-175), Weinhold (1999) and Nair-Reichert \& Weinhold (2001, pp. 193-171) use a Mixed Fixed and Random Model to evaluate Granger causality. A differ-

economies are those with a GNI per capita of more than $\$ 1,045$ but less than $\$ 12,746$; highincome economies are those with a GNI per capita of $\$ 12,746$ or more. Lower-middleincome and upper-middle-income economies are separated at a GNI per capita of $\$ 4,125$. See http://data.worldbank.org/news/2015-country-classifications.

${ }^{6}$ The Atlas conversion factor for any year is the average of a country's exchange rate for that year and its exchange rates for the two preceding years, adjusted for the difference between the rate of inflation in the country and international inflation. https://datahelpdesk.worldbank.org/knowledgebase/articles/378832-what-is-the-world-bankatlas-method. 
ent approach is used by Hurlin \& Venet (2001, pp. 3-19), who assume that the parameters of the regression are fixed and propose a wide procedure for testing causality. In this paper, the Hurlin and Venet approach is applied.

When using panel data, we expect heterogeneity between individuals to be for two reasons. The first reason is a natural cross-sectional difference between panel units. This type of heterogeneity is taken into account by separating individual fixed effects $\alpha_{i}$ from random disturbances $v_{i t}$.

Applying this to equation 2, we treat $v_{i t}$ as the sum of individual effects $\alpha_{i}$ and random disturbances $\varepsilon_{i t}$ and impose the following assumptions on $\alpha_{i}$ and $\varepsilon_{i t}$ :

$$
\begin{aligned}
& \alpha_{i} \sim \operatorname{IID}\left(0, \sigma_{\alpha}^{2}\right), \varepsilon_{i t} \sim \operatorname{IID}\left(0, \sigma_{\varepsilon}^{2}\right) \\
& E\left(\alpha_{i} \varepsilon_{i t}\right)=0 \\
& E\left(\alpha_{i} \alpha_{j}\right)=E\left(\varepsilon_{i t} \varepsilon_{j s}\right)=0, \text { for } i \neq j \text { and } t \neq s \\
& E\left(\alpha_{i} x_{i t}\right)=E\left(\varepsilon_{i t} x_{i t}\right)=0 .
\end{aligned}
$$

The second reason for heterogeneity among panel units follows from there being two subgroups within the whole group - a subgroup where causality between $x$ and $y$ exists $\left(\beta_{\mathrm{i}}{ }^{(\mathrm{k})} \neq 0\right)$ and a subgroup where the causal relationship is not observed $\left(\beta_{\mathrm{i}}^{(\mathrm{k})}=0\right)$. The assumptions concerning the model coefficients are as follows:

- the autoregressive parameters $\gamma^{(\mathrm{k})}$ and coefficient slopes $\beta_{\mathrm{i}}{ }^{(\mathrm{k})}$ are constant for all lags;

- the autoregressive coefficients $\gamma^{(\mathrm{k})}$ are identical for all individuals but the regression coefficient slopes $\beta_{i}{ }^{(\mathrm{k})}$ may vary between individuals.

The strategy for testing Granger causality proposed by Hurlin \& Venet (2001) is presented in Table 3.

The procedure consists of 3 steps. First, the Homogeneous NonCausality (HNC) hypothesis is tested. When the null cannot be rejected, it means that no individual Granger causality is observed. Otherwise, the second step of the procedure is needed. This step consists in checking whether the group analysed is homogeneous or not. The last step allows the question of there being a subgroup of individuals for which causality is observed and a subgroup for which the causal relationship does not exist to be answered.

The literature on dynamic panel data models provides a wide discussion on properties of standard estimators in particular in a context of their biasness. Hurlin \& Venet (2001, p. 22) assume that when a time dimension is sufficient $(\mathrm{T}=31)$, the dynamic panel bias can be treated as insignificant and LSDV estimator can be used. In a case of small T-dimension the dynamic 
bias should be taken into consideration. As Judson and Owen (1999, p. 13) note, the best choice for short and balanced dynamic panels is corrected LSDV estimator proposed by Kiviet (1995), however it cannot be used when the order of autoregression is higher than 1. According to Judson and Owen (1999, p. 13) the second best solution is GMM estimator which is applied in our investigation.

Table 3. Hypotheses and test statistics in Granger's causality test for panel data models

\section{Hypotheses}

Test statistics

STEP I

$$
\begin{aligned}
& H_{0}: \beta_{i}^{(k)}=0 \forall i=1, \ldots, N \forall k=1, \ldots, p \quad F_{H N C}=\frac{\left(R S S_{2}-R S S_{1}\right) / N p}{R S S_{1} /(N T-N(1+p)-p)} \\
& H_{1}: \exists(i, k) \beta_{i}^{(k)} \neq 0
\end{aligned}
$$

\section{STEP II}

$$
\begin{aligned}
& H_{0}: \forall k=1, \ldots, p / \beta_{i}^{k}=\beta_{i} \quad \forall i=1, \ldots, N \\
& H_{1}: \exists k \in[1, p], \exists(i, j) \in[1, N] / \beta_{i}^{k} \neq \beta_{j}^{k} \quad F_{H C}=\frac{\left(R S S_{3}-R S S_{1}\right) /(N-1) p}{R S S_{1} /(N T-N(1+p)-p)}
\end{aligned}
$$

\section{STEP III}

$$
\begin{aligned}
& H_{0}: \exists i \in[1, N] / \forall k \in[1, p] \beta_{i}^{k}=0 \\
& H_{1}: \forall i=1, \ldots, N \exists k \in[1, p] / \beta_{i}^{k} \neq 0
\end{aligned} \quad F_{H E N C}=\frac{\left(R S S_{2, i}-R S S_{1}\right) / p}{R S S_{1} /(N T-N(1+2 p)+p)}
$$

Source: own elaboration based on Hurlin and Venet (2001).

\section{Results}

The procedure for evaluating Granger causality is based on a timestationary VAR model. For the purpose of evaluating unit-root presence we use two panel unit root tests: the Harris-Tzavalis test (Harris \& Tzavalis, 1999, pp. 201-226) (HT) and the Im-Pesaran-Shin test (Im et al., 2003, pp. 53-74) (IPS), which are chosen in the light of the sample size. Additionally, 
in the HT test a small-sample adjustment to $T$ is made. Both tests are applied for each of the five income groups: low-income countries (LI), lowermiddle-income countries (LMI), upper-middle-income countries (UMI), high-income non-OECD countries (HnOECD) and high-income OECD countries (HOECD). The results of the tests are presented in Table 4.

Table 4. Results for panel unit root tests

\begin{tabular}{|c|c|c|c|c|c|}
\hline & \multicolumn{5}{|c|}{ GDP growth } \\
\hline & LI & LMI & UMI & HnOECD & HOECD \\
\hline \multirow{2}{*}{ HT } & -0.016 & -0.179 & -0.080 & 0.314 & 0.007 \\
\hline & $*$ & $* * *$ & $* * *$ & $* * *$ & $* * *$ \\
\hline \multirow{4}{*}{ F-ADF } & 75.733 & 126.166 & 176.151 & 45.314 & 188.401 \\
\hline & *** & $* * *$ & $* * *$ & $* *$ & $* * *$ \\
\hline & \multicolumn{5}{|c|}{ Global Competitiveness Index } \\
\hline & $\mathbf{L I}$ & LMI & UMI & HnOECD & HOECD \\
\hline \multirow{2}{*}{ HT } & 0.174 & 0.218 & 0.268 & 0.605 & 0.605 \\
\hline & $*$ & $*$ & & & $* *$ \\
\hline \multirow{2}{*}{ F-ADF } & 47.373 & 73.294 & 76.285 & 42.083 & 80.110 \\
\hline & $* *$ & $* *$ & $* *$ & $*$ & $*$ \\
\hline
\end{tabular}

Source: own estimation.

For GDP growth, both the Harris-Tzavalis and the IPS test allow for the null hypothesis that the GDP growth time series contains a unit root to be rejected. For the Global Competitiveness Index, the IPS test is significant for all the groups as well, but the HT test for UMI and HnOECD countries does not reject the null.

Finally, we can treat both variables as time-stationary and start the procedure for Granger causality evaluation, which is based on two regressions, estimated for each income group separately:

$$
\begin{gathered}
\Delta G D P_{i, t}=\sum_{k=1}^{p} \gamma^{(k)} \Delta G D P_{i, t-k}+\sum_{k=0}^{p} \beta_{i}^{(k)} G C I_{i, t-k}+v_{i, t}, \\
G C I_{i, t}=\sum_{k=1}^{p} \gamma^{(k)} G C I_{i, t-k}+\sum_{k=0}^{p} \beta_{i}^{(k)} \Delta G D P_{i, t-k}+v_{i, t} .
\end{gathered}
$$




\section{Aleksandra Kordalska, Magdalena Olczyk}

Due to the shortness of the time series, the number of lags in regressions 4 and 5 are limited to $\mathrm{k}=2$.

Following Table 3, we first explore whether in the homogeneous sample one can observe bidirectional causality, unidirectional causality or we cannot reject the null. Taking each income group individually, we can strongly reject the homogeneous non-causality hypothesis (Table 5). A causal relationship from the Global Competitiveness Index to GDP growth and for the relation $\Delta \mathrm{GDP} \rightarrow \mathrm{GCI}$ exists for all the lags tested, except for the relation $\mathrm{GCI} \rightarrow \Delta \mathrm{GDP}$ for low middle-income countries with one lag only.

Table 5. Results for the Homogenous Non-Causality hypothesis

\begin{tabular}{|c|c|c|c|c|c|}
\hline \multirow[b]{2}{*}{ lag } & \multicolumn{5}{|c|}{ Global Competitiveness Index $\rightarrow$ GDP growth } \\
\hline & LI & LMI & UMI & HnOECD & HOECD \\
\hline \multirow{2}{*}{1} & 1,721 & 0,606 & 5,370 & 2,335 & 19,568 \\
\hline & $*$ & & $* * *$ & $* * *$ & $* * *$ \\
\hline \multirow{3}{*}{2} & 33,011 & 26,502 & 130,193 & 29,849 & 8,600 \\
\hline & $* * *$ & $* * *$ & $* * *$ & $* * *$ & $* * *$ \\
\hline & \multicolumn{5}{|c|}{ GDP growth $\rightarrow$ Global Competitiveness Index } \\
\hline lag & LI & LMI & UMI & HnOECD & HOECD \\
\hline \multirow{2}{*}{1} & 3,552 & 2,617 & 5,164 & 3,274 & 2,413 \\
\hline & $* * *$ & $* * *$ & $* * *$ & $* * *$ & $* * *$ \\
\hline \multirow{2}{*}{2} & 4,395 & 2,948 & 2,749 & 4,391 & 6,296 \\
\hline & $* * *$ & $* * *$ & $* * *$ & $* * *$ & $* * *$ \\
\hline
\end{tabular}

Source: own estimation.

The next step is to examine whether the relationship between the competitiveness measure and GDP changes is strictly homogeneous or not in the counties which belong to each income group. The results are reported in Table 6. We reject the Homogeneous Causality hypothesis, which is in line with our expectations. The pattern of rejection is quite similar to the first step. For the relationship from GCI to GDP growth and the relation in the opposite direction with one lag for low middle income countries we cannot reject the HC hypothesis. Except for these cases, in general we observe a differentiation in respect of causality according to the group that the countries analysed belong to. 
Table 6. Results for the Homogeneous Causality hypothesis

\begin{tabular}{|c|c|c|c|c|c|}
\hline & \multicolumn{5}{|c|}{ Global Competitiveness Index $\rightarrow$ GDP growth } \\
\hline lag & LI & LMI & UMI & HnOECD & HOECD \\
\hline \multirow{2}{*}{1} & 1,688 & 0,539 & 5,208 & 2,426 & 18,662 \\
\hline & $*$ & & $* * *$ & $* * *$ & $* * *$ \\
\hline \multirow{3}{*}{2} & 31,471 & 22,780 & 115,478 & 30,189 & 8,307 \\
\hline & $* * *$ & *** & $* * *$ & $* * *$ & $* * *$ \\
\hline & \multicolumn{5}{|c|}{ GDP growth $\rightarrow$ Global Competitiveness Index } \\
\hline lag & LI & LMI & UMI & HnOECD & HOECD \\
\hline \multirow{2}{*}{1} & 4,394 & 1,243 & 3,105 & 3,193 & 0,388 \\
\hline & $* * *$ & & $* * *$ & $* * *$ & \\
\hline \multirow{2}{*}{2} & 5,031 & 2,567 & 1,587 & 2,635 & 2,921 \\
\hline & $* * *$ & $* * *$ & $* *$ & $* * *$ & $* * *$ \\
\hline
\end{tabular}

* $\quad$ significant at $0.1 \%, * *$ significant at $0.05 \%, * * *$ significant at $0.01 \%$

Source: own estimation.

Given the rejection of the HC hypothesis, the HENC hypothesis should be tested. We are interested in the subgroup of countries among each income group for which the causal relationship does not exist, neither from GDP growth to GCI nor from GCI to GDP growth, both for which we can observe a one-way relationship and for which the relationship is bidirectional. The results are reported in Tables 7, 8, 9, 10 and 11 for LI countries, LMI countries, UMI countries, HnOECD countries and HOECD countries respectively.

Table 7. Results for the Heterogeneous Non-Causality hypothesis - low-income countries

\begin{tabular}{|c|c|c|c|c|c|c|c|}
\hline \multirow{3}{*}{$\begin{array}{c}\text { LI } \\
\text { Bangladesh }\end{array}$} & \multicolumn{3}{|c|}{$\begin{array}{c}\text { Global Competitiveness Index } \\
\rightarrow \text { GDP growth }\end{array}$} & \multicolumn{4}{|c|}{$\begin{array}{l}\text { GDP growth } \rightarrow \\
\text { Global Competitiveness Index }\end{array}$} \\
\hline & \multicolumn{2}{|c|}{$\operatorname{lag} 1$} & lag2 & \multicolumn{2}{|c|}{ lag 1} & \multicolumn{2}{|c|}{ lag2 } \\
\hline & 17,729 & $* * *$ & 7,826 & 4,046 & $* *$ & 5,449 & $* * *$ \\
\hline Burkina Faso & 5,435 & $* *$ & 0,274 & 76,781 & $* * *$ & 0,148 & \\
\hline Burundi & 5,345 & $* *$ & 0,157 & 32,577 & $* * *$ & 16,066 & $* * *$ \\
\hline Cambodia & 5,278 & $* *$ & 1,186 & 1,575 & & 5,495 & $* * *$ \\
\hline Chad & 5,510 & $* *$ & 2,144 & 5,819 & $* *$ & 0,792 & \\
\hline Ethiopia & 6,034 & $* *$ & 1,938 & 1,435 & & 7,273 & $* * *$ \\
\hline
\end{tabular}




\section{Aleksandra Kordalska, Magdalena Olczyk}

Table 7 continued

\begin{tabular}{|c|c|c|c|c|c|c|c|}
\hline \multirow{3}{*}{$\begin{array}{r}\text { LI } \\
\text { Gambia }\end{array}$} & \multicolumn{3}{|c|}{$\begin{array}{c}\text { Global Competitiveness Index } \\
\rightarrow \text { GDP growth }\end{array}$} & \multicolumn{4}{|c|}{$\begin{array}{l}\text { GDP growth } \rightarrow \\
\text { Global Competitiveness Index }\end{array}$} \\
\hline & \multicolumn{2}{|c|}{ lag 1} & \multirow{2}{*}{$\begin{array}{r}\text { lag2 } \\
0,121\end{array}$} & \multicolumn{2}{|c|}{$\operatorname{lag} 1$} & \multicolumn{2}{|c|}{ lag2 } \\
\hline & 5,345 & $* *$ & & 1,577 & & 3,594 & $* *$ \\
\hline Kenya & 6,001 & $* *$ & 1,273 & 2,827 & $*$ & 8,380 & $* * *$ \\
\hline Madagascar & 5,388 & $* *$ & 0,119 & 0,454 & & 0,140 & \\
\hline Mali & 5,368 & $* *$ & 0,154 & 5,104 & $* *$ & 2,325 & \\
\hline Mozambique & 5,392 & $* *$ & 0,250 & 10,221 & $* * *$ & 1,417 & \\
\hline Nepal & 5,497 & $* *$ & 0,376 & 2,727 & & 3,190 & $* *$ \\
\hline Tanzania & 6,317 & $* *$ & 2,104 & 0,582 & & 2,593 & $*$ \\
\hline Uganda & 5,487 & $* *$ & 1,761 & 4,821 & $* *$ & 1,801 & \\
\hline Zimbabwe & 5,325 & $* *$ & 0,390 & 14,469 & $* * *$ & 2,078 & \\
\hline
\end{tabular}

* significant at $0.1 \%, * *$ significant at $0.05 \%, * * *$ significant at $0.01 \%$

Source: own estimation.

Table 8. Results for the Heterogeneous Non-Causality hypothesis - lower-middleincome countries

\begin{tabular}{|c|c|c|c|c|c|}
\hline \multirow{2}{*}{ LMI } & \multicolumn{2}{|c|}{$\begin{array}{c}\text { Global Competitiveness Index } \\
\rightarrow \text { GDP growth }\end{array}$} & \multicolumn{3}{|c|}{$\begin{array}{l}\text { GDP growth } \rightarrow \\
\text { Global Competitiveness Index }\end{array}$} \\
\hline & $\operatorname{lag} 1$ & lag2 & $\operatorname{lag} 1$ & lag2 & \\
\hline Armenia & 0,137 & 0,002 & 0,696 & 0,769 & \\
\hline Bolivia & 0,151 & 0,002 & 1,529 & 0,863 & \\
\hline Cameroon & 0,140 & 0,000 & 0,325 & 0,266 & \\
\hline Egypt & 0,120 & 0,066 & 2,715 & 3,003 & $* *$ \\
\hline El Salvador & 0,140 & 0,003 & 1,255 & 2,086 & \\
\hline Georgia & 0,140 & 0,003 & 0,056 & 1,324 & \\
\hline Guatemala & 0,145 & 0,000 & 2,592 & 1,686 & \\
\hline Guyana & 0,138 & 0,000 & 0,548 & 1,574 & \\
\hline Honduras & 0,142 & 0,002 & 1,543 & 1,738 & \\
\hline India & 3,001 & 5,149 & 0,790 & 8,214 & $* * *$ \\
\hline Indonesia & 0,296 & 0,424 & 1,751 & 7,678 & $* * *$ \\
\hline Kyrgyz Republic & 0,138 & 0,000 & 1,286 & 2,417 & $*$ \\
\hline Lesotho & 0,136 & 0,001 & 0,627 & 1,076 & \\
\hline Mauritania & 0,137 & 0,000 & 2,712 & 6,660 & $* * *$ \\
\hline
\end{tabular}


Table 8 continued

\begin{tabular}{|c|c|c|c|c|c|c|}
\hline \multirow{2}{*}{ LMI } & \multicolumn{2}{|c|}{$\begin{array}{c}\text { Global Competitiveness Index } \\
\rightarrow \text { GDP growth } \\
\end{array}$} & \multicolumn{4}{|c|}{$\begin{array}{l}\text { GDP growth } \rightarrow \\
\text { Global Competitiveness Index }\end{array}$} \\
\hline & $\operatorname{lag} 1$ & lag2 & lag & & lag2 & \\
\hline Mongolia & 0,141 & 0,001 & 1,198 & & 5,417 & $* * *$ \\
\hline Morocco & 0,147 & 0,010 & 0,034 & & 2,083 & \\
\hline Nicaragua & 0,141 & 0,002 & 0,324 & & 1,451 & \\
\hline Nigeria & 0,356 & 0,147 & 2,023 & & 18,939 & $* * *$ \\
\hline Pakistan & 0,035 & 0,260 & 1,424 & & 3,385 & $* *$ \\
\hline Paraguay & 0,140 & 0,008 & 4,426 & $* *$ & 1,545 & \\
\hline Philippines & 0,146 & 0,095 & 4,060 & $* *$ & 3,415 & $* *$ \\
\hline Sri Lanka & 0,147 & 0,002 & 0,826 & & 2,675 & $*$ \\
\hline Timor-Leste & 0,148 & 0,040 & 1,627 & & 5,204 & $* * *$ \\
\hline Ukraine & 0,028 & 1,723 & 0,103 & & 6,434 & $* * *$ \\
\hline Vietnam & 0,150 & 0,005 & 0,367 & & 1,545 & \\
\hline Zambia & 0,142 & 0,000 & 1,677 & & 0,573 & \\
\hline
\end{tabular}

* $\quad$ significant at $0.1 \%, * *$ significant at $0.05 \%, * * *$ significant at $0.01 \%$

Source: own estimation.

Table 9. Results for the Heterogeneous Non-Causality hypothesis - upper-middleincome countries

\begin{tabular}{|c|c|c|c|c|c|c|c|}
\hline \multirow[t]{2}{*}{ UMI } & \multicolumn{3}{|c|}{$\begin{array}{c}\text { Global Competitiveness Index } \\
\text { growth }\end{array}$} & \multicolumn{4}{|c|}{$\begin{array}{l}\text { GDP growth } \rightarrow \\
\text { Global Competitiveness } \\
\text { Index } \\
\end{array}$} \\
\hline & $\operatorname{lag} 1$ & \multicolumn{2}{|l|}{ lag2 } & \multicolumn{2}{|c|}{ lag 1} & \multicolumn{2}{|c|}{$\operatorname{lag} 2$} \\
\hline Albania & 1,423 & 0,016 & & 2,645 & & 1,240 & \\
\hline Algeria & 1,435 & 0,000 & & 13,814 & $* * *$ & 6,738 & $* * *$ \\
\hline Argentina & 1,502 & 0,369 & & 9,543 & $* * *$ & 2,549 & $*$ \\
\hline Azerbaijan & 1,442 & 0,029 & & 2,200 & & 0,917 & \\
\hline Botswana & 1,423 & 0,017 & & 21,158 & $* * *$ & 7,016 & $* * *$ \\
\hline Brazil & 1,902 & 1,141 & & 9,272 & $* * *$ & 4,260 & $* *$ \\
\hline Bulgaria & 1,431 & 0,039 & & 0,750 & & 0,227 & \\
\hline China & 97,238 & 27,990 & $* * *$ & 0,131 & & 1,420 & \\
\hline
\end{tabular}


Table 9 continued

\begin{tabular}{|c|c|c|c|c|c|c|}
\hline \multirow[t]{2}{*}{ UMI } & \multicolumn{2}{|c|}{$\begin{array}{c}\text { Global Competitiveness Index } \rightarrow \\
\text { GDP growth }\end{array}$} & \multicolumn{4}{|c|}{$\begin{array}{c}\text { GDP growth } \rightarrow \\
\text { Global Competitiveness Index }\end{array}$} \\
\hline & $\operatorname{lag} 1$ & $\operatorname{lag} 2$ & lag & & lag2 & \\
\hline Colombia & 1,470 & 0,435 & 1,333 & & 0,277 & \\
\hline Costa Rica & 1,424 & 0,017 & 1,010 & & 0,688 & \\
\hline $\begin{array}{l}\text { Dominican } \\
\text { Republic } \\
\end{array}$ & 1,431 & 0,038 & 2,924 & $*$ & 1,110 & \\
\hline Hungary & 1,421 & 0,057 & 9,232 & $* * *$ & 2,546 & $*$ \\
\hline Jamaica & 1,424 & 0,015 & 8,430 & $* * *$ & 2,674 & $*$ \\
\hline Jordan & 1,423 & 0,018 & 2,964 & $*$ & 1,638 & \\
\hline Kazakhstan & 1,466 & 0,072 & 5,644 & $* *$ & 1,545 & \\
\hline $\begin{array}{l}\text { Macedonia, } \\
\text { FYR }\end{array}$ & 1,422 & 0,016 & 2,915 & $*$ & 0,477 & \\
\hline Malaysia & 1,501 & 0,229 & 3,631 & $*$ & 2,815 & $*$ \\
\hline Mauritius & 1,421 & 0,016 & 1,874 & & 0,676 & \\
\hline Mexico & 1,720 & 1,035 & 2,256 & & 0,990 & \\
\hline Namibia & 1,419 & 0,016 & 9,050 & $* * *$ & 2,849 & $*$ \\
\hline Panama & 1,435 & 0,020 & 1,879 & & 1,167 & \\
\hline Peru & 1,489 & 0,096 & 7,112 & $* * *$ & 1,989 & \\
\hline Romania & 1,453 & 0,024 & 0,764 & & 0,780 & \\
\hline South Africa & 1,330 & 0,083 & 3,176 & $*$ & 0,555 & \\
\hline Thailand & 1,519 & 0,043 & 1,360 & & 1,958 & \\
\hline Turkey & 1,514 & 1,065 & 3,014 & $*$ & 1,715 & \\
\hline Venezuela & 1,575 & 0,587 & 14,366 & $* * *$ & 4,493 & $* *$ \\
\hline
\end{tabular}

* significant at $0.1 \%, * *$ significant at $0.05 \%, * * *$ significant at $0.01 \%$

Source: own estimation. 
Table 10. Results for the Heterogeneous Non-Causality hypothesis - Non-OECD high-income countries

\begin{tabular}{|c|c|c|c|c|c|c|c|}
\hline \multirow{2}{*}{ HnOECD } & \multicolumn{3}{|c|}{$\begin{array}{c}\text { Global Competitiveness Index } \\
\rightarrow \text { GDP growth }\end{array}$} & \multicolumn{4}{|c|}{$\begin{array}{l}\text { GDP growth } \rightarrow \\
\text { Global Competitiveness Index }\end{array}$} \\
\hline & $\operatorname{lag} 1$ & $\operatorname{lag} 2$ & & lag & & las & \\
\hline Bahrain & 0,019 & 0,241 & & 1,262 & & 1,696 & \\
\hline Barbados & 0,015 & 0,233 & & 3,875 & $*$ & 0,473 & \\
\hline Croatia & 0,084 & 0,582 & & 0,938 & & 3,127 & $* *$ \\
\hline Cyprus & 0,046 & 0,494 & & 4,612 & $* *$ & 8,055 & $* * *$ \\
\hline $\begin{array}{l}\text { Hong Kong } \\
\text { SAR }\end{array}$ & 0,029 & 1,020 & & 21,536 & $* * *$ & 6,212 & $* * *$ \\
\hline Kuwait & 0,476 & 0,192 & & 2,072 & & 1,316 & \\
\hline Latvia & 0,015 & 0,294 & & 7,472 & $* * *$ & 3,803 & $* *$ \\
\hline Lithuania & 0,027 & 0,392 & & 1,572 & & 0,531 & \\
\hline Malta & 0,104 & 0,460 & & 0,048 & & 0,540 & \\
\hline Qatar & 0,495 & 0,456 & & 6,526 & $* *$ & 3,674 & $* *$ \\
\hline $\begin{array}{l}\text { Russian } \\
\text { Federation }\end{array}$ & $27,116 \quad * * *$ & 125,522 & $* * *$ & 2,634 & & 1,399 & \\
\hline Singapore & 1,791 & 1,685 & & 17,584 & $* * *$ & 2,206 & \\
\hline $\begin{array}{l}\text { Trinidad and } \\
\text { Tobago }\end{array}$ & 0,016 & 0,240 & & 4,695 & & 1,634 & \\
\hline $\begin{array}{l}\text { United Arab } \\
\text { Emirates }\end{array}$ & 0,239 & 2,832 & $*$ & 18,998 & $* * *$ & 6,948 & $* * *$ \\
\hline Uruguay & 0,013 & 0,217 & & 0,981 & & 0,298 & \\
\hline
\end{tabular}

Source: own estimation.

Table 11. Results for the Heterogeneous Non-Causality hypothesis - OECD highincome countries

\begin{tabular}{lcccccc}
\hline \multirow{2}{*}{ HOECD } & \multicolumn{2}{c}{ Global Competitiveness Index } & \multicolumn{2}{c}{ GDP growth $\rightarrow$} \\
& \multicolumn{2}{c}{$\boldsymbol{\rightarrow}$ GDP growth } & Global Competitiveness Index \\
\cline { 2 - 7 } & \multicolumn{2}{c}{ lag $\mathbf{1}$} & lag2 & \multicolumn{1}{c}{ lag $\mathbf{1}$} & lag2 \\
\hline Australia & 4,665 & $* *$ & 0,176 & 0,521 & 0,639 \\
\hline Austria & 4,170 & $* *$ & 0,201 & 7,925 & $* * *$ & 2,250 \\
\hline Belgium & 4,119 & $* *$ & 0,196 & 4,275 & $* *$ & 1,663 \\
\hline Canada & 4,494 & $* *$ & 0,217 & 2,627 & 0,318 \\
\hline Chile & 4,285 & $* *$ & 0,299 & 4,546 & $* *$ & 0,900 \\
\hline
\end{tabular}


Table 11 continued

\begin{tabular}{|c|c|c|c|c|c|c|c|c|}
\hline \multirow{3}{*}{$\begin{array}{c}\text { HOECD } \\
\text { Czech Republic } \\
\end{array}$} & \multicolumn{4}{|c|}{$\begin{array}{c}\text { Global Competitiveness Index } \\
\rightarrow \text { GDP growth } \\
\end{array}$} & \multicolumn{4}{|c|}{$\begin{array}{l}\text { GDP growth } \rightarrow \\
\text { Global Competitiveness Index }\end{array}$} \\
\hline & \multicolumn{2}{|c|}{$\operatorname{lag} 1$} & \multicolumn{2}{|c|}{ lag2 } & \multicolumn{2}{|c|}{$\operatorname{lag} 1$} & \multicolumn{2}{|l|}{ lag2 } \\
\hline & 4,087 & $* *$ & 0,145 & & 1,862 & & 0,880 & \\
\hline Denmark & 4,069 & $* *$ & 0,131 & & 0,730 & & 3,045 & $* *$ \\
\hline Estonia & 4,065 & $* *$ & 0,129 & & 2,459 & & 1,263 & \\
\hline Finland & 4,110 & $* *$ & 0,167 & & 0,822 & & 2,199 & \\
\hline France & 4,483 & $* *$ & 1,272 & & 4,297 & $* *$ & 1,066 & \\
\hline Germany & 4,701 & $* *$ & 4,092 & $* *$ & 24,838 & $* * *$ & 4,949 & $* * *$ \\
\hline Greece & 4,057 & $* *$ & 0,151 & & 6,074 & $* *$ & 1,837 & \\
\hline Iceland & 4,060 & $* *$ & 0,126 & & 4,228 & $* *$ & 1,589 & \\
\hline Ireland & 4,067 & $* *$ & 0,172 & & 0,426 & & 3,265 & $* *$ \\
\hline Israel & 4,250 & $* *$ & 0,136 & & 17,741 & $* * *$ & 14,639 & $* * *$ \\
\hline Italy & 3,957 & $* *$ & 1,767 & & 2,455 & & 0,504 & \\
\hline Japan & 5,083 & $* *$ & 1,638 & & 9,014 & $* * *$ & 3,254 & $* *$ \\
\hline Korea, Rep. & 4,777 & $* *$ & 0,282 & & 100,821 & $* * *$ & 8,393 & $* * *$ \\
\hline Luxembourg & 4,056 & $* *$ & 0,127 & & 0,878 & & 2,559 & $*$ \\
\hline Netherlands & 4,064 & $* *$ & 0,410 & & 8,832 & $* * *$ & 1,566 & \\
\hline New Zealand & 4,102 & $* *$ & 0,134 & & 3,032 & $*$ & 2,832 & $*$ \\
\hline Norway & 4,130 & $* *$ & 0,170 & & 8,906 & $* * *$ & 1,415 & \\
\hline Poland & 4,417 & $* *$ & 0,196 & & 3,288 & $*$ & 0,506 & \\
\hline Portugal & 4,051 & $* *$ & 0,124 & & 2,386 & & 0,059 & \\
\hline Slovak Republic & 4,109 & $* *$ & 0,143 & & 11,726 & $* * *$ & 1,469 & \\
\hline Slovenia & 4,085 & $* *$ & 0,129 & & 4,358 & $* *$ & 5,162 & $* * *$ \\
\hline Spain & 7,101 & $* * *$ & 0,929 & & 7,254 & $* * *$ & 3,235 & $* *$ \\
\hline Sweden & 4,125 & $* *$ & 0,246 & & 7,617 & $* * *$ & 3,118 & $* *$ \\
\hline Switzerland & 4,189 & $* *$ & 0,160 & & 13,874 & $* * *$ & 3,208 & $* *$ \\
\hline United Kingdom & 4,246 & $* *$ & 2,038 & & 15,098 & $* * *$ & 5,750 & $* * *$ \\
\hline United States & 79,666 & $* * *$ & 165,927 & $* * *$ & 5,552 & $* *$ & 4,579 & $* *$ \\
\hline
\end{tabular}

* significant at $0.1 \%, * *$ significant at $0.05 \%, * * *$ significant at $0.01 \%$

Source: own estimation.

The results suggest that regardless of the income group, the relationship from GDP growth to the Global Competitiveness Index is more often observed than the opposite one. It is interesting that only for majority of coun- 
tries from two groups: low income and high OECD income, we observe a strong significant influence of the GCI on the growth rate of GDP, in turn in the middle income countries, we found this relationship statistically important only for large economies such as India and China.

A two-way relationship between competitiveness and economic growth is observed for 13 out of 15 low income countries and for 24 out of 31 OECD high income countries.

\section{Conclusions}

This paper has tested whether the GCI is a reliable predictor of economic growth or whether the growth rate can be believed to predict the global competitiveness of a country. Our empirical study, first done at the country group level, indicates a quite strong bidirectional causality between the Global Competitiveness Index and the economic growth rate for all the lags tested. The exception is the group of lower middle income countries, where a relationship from the GCI to GDP growth is significant for two lags only.

We have also examined the kind of causality. The results were in line with our expectations. All the groups analysed turned out to be heterogeneous except for LMI countries and one lag tested.

The last step of our investigation was to assess the direction of the relationship between the GCI and the growth rate of GDP at the level of individual countries within each of the five groups of countries. The results of our estimations confirm that economic growth affects global competitiveness in the case of $66 \%$ of the countries in our sample. Most often this relationship exists among low income countries (in 14 out of 15 economies i.e. for $93 \%$ of the countries analysed). In turn, it is relatively rare among middle income countries (in 50\% of the lower middle-income countries and in 59\% the upper middle-income countries).

Finally, we have confirmed that the GCI can predict the dynamics of a national economy, but only in some particular cases. We can support the WEF's claim that the GCI can "determine the aggregate growth rates of an economy" for two groups i.e. low-income and OECD high income countries. For almost 14 of the 15 countries with a lower income level we can justify the contribution of their global competiveness level to their economic growth during the last decade. This evolution is probably due to a large number of economic reforms in these countries and good political stability, which affect capital accumulation and finally economic growth. Among the countries with a higher level of income, the causal relationship from the Global Competitiveness Index to GDP growth exists for majority of OECD 
countries. For countries with the middle income this relationship we found only for large economies such as China and India. Our study has a preliminary character, but its results imply that the WEF should refine GCI so that it can be a better predictor of economic growth.

\section{References}

Aghion, P., \& Howitt, P. (1992). A Model of Growth through Creative Destruction. Econometrica, 60(2). http://dx.doi.org/10.2307/2951599.

Bai, S. (2009). Measuring Financial Integration in the BRIC Nations. International Journal of Services and Standards, 5(3). http://dx.doi.org/10.1504/ IJSS.2009.028676.

Barro, R. (1990). Government Spending in a Simple Model of Economic Growth. Journal of Political Economy, 98(5). http://dx.doi.org/10.1086/261726.

Ben Amar, M., \& Hamdi, M. T. (2012). Global Competitiveness and Economic Growth: Empirical Verification for African Countries. International Journal of Economics and Finance, 4(6). http://dx.doi.org/10.5539/ijef.v4n6p125.

Berger, T. (2008). Concepts on National Competitiveness. Journal of International Business and Economy, 9(1).

Berger, T. \& Bristow, G. (2009). Competitiveness and the Benchmarking of Nations - A Critical Reflection. International Advances in Economic Research, 15(4). http://dx.doi.org/10.1007/s11294-009-9231-x.

Boltho, A. (1996). The assessment: international competitiveness. Oxford Review of Economic Policy, 12(3). http://dx.doi.org/10.1093/oxrep/12.3.1.

Carvalho, L., Di Serio, L. \& Vasconcellos, M. (2012). Competitiveness of Nations: Review of the Metric Used by the World Economic Forum. Revista de Administração de Empresas, 52(4). http://dx.doi.org/10.1590/S0034-7590201200 0400005.

Chamberlain, G. (1984). Panel Data. In Z. Griliches \& M. D. Intriligator (Eds.). Handbook of Econometrics volume II. Amsterdam: North - Holland Publishing Co.

Davies, H. \& Ellis, P. D. (2000). Porter's 'Competitive Advantage of Nations': Time for a final judgment? Journal of Management Studies, 37(8). http://dx.doi.org/10.1111/1467-6486.00221.

Dunning, J. H. (1992). Multinational enterprises and the global economy. Wokingham, UK and Reading, MA: Addison-Wesley Publishing Company.

Dunning, J. H. (1993). The globalization of business. London and New York: Routledge.

Freudenberg, M. (2003). Composite Indicators of Country Performance: A Critical Assessment, OECD Science, Technology and Industry Working Papers, 2003/16. http://dx.doi.org/10.1787/405566708255. 
Garden, C., \& Martin, R. L. (2005). A Study on the Factors of Regional Competitiveness: A Draft Final Report for the European Commission DirectorateGeneral Regional Policy. Retrieved from http://ec.europa.eu/regional_policy/ sources/docgener/studies/pdf/3cr/competiti veness.pdf (2.03.2015).

Grossman, G., \& Helpman, E. (1991). Quality Ladders and Product Cycles. Quarterly Journal of Economics, 106(2). http://dx.doi.org/10.2307/2937947.

Harris, R. D. F., \& Tzavalis, E. (1999). Inference for Unit Roots in Dynamic Panels where the Time Dimension is Fixed. Journal of Econometrics, 91(2). http://dx.doi.org/10.1016/S0304-4076(98)00076-1.

Holtz-Eakin, D., Newey W., \& Rosen, H. (1985). Implementing Causality Tests with Panel Data, with an Example from Fiscal Public Finance. NBER Technical Working Paper, 48. http://dx.doi.org/10.3386/t0048.

Hsiao, C. (1989). Modelling Ontario Regional Electricity System Demand Using a Mixed Fixed and Random Coefficients Approach. Regional Science and Urban Economics, 19(4). http://dx.doi.org/10.1016/0166-0462(89)90020-3.

Hurlin, C., \& Venet, B. (2001). Granger Causality Tests in Panel Data Models with Fixed Coefficients. EURIsCO Université Paris Dauphine, 2001-09.

Im, K. S., Pesaran, M. H., \& Shin, Y. (2003). Testing for unit roots in heterogeneous panels. Journal of Econometrics, 115(1). http://dx.doi.org/10.1016/S03044076(03)00092-7.

Judson, R. A., Owen A. L. (1999). Estimating dynamic panel data models: a guide for macroeconomists. Economics Letters, 65(1). http://dx.doi.org/10.1016 IS0165-1765(99)00130-5.

Kiviet, J. F. (1995). On bias, inconsistency, and efficiency of various estimators in dynamic panel data models. Journal of Econometrics, 68(1). http://dx.doi.org/1 0.1016/0304-4076(94)01643-E.

Koong, K. S., Flores, J., Sun, J. \& Liu, L. C. (2011). Health information technology performance measures: a lifecycle analysis. International Journal of Services and Standards, 7(3/4). http://dx.doi.org/10.1504/IJSS.2011.045048.

Lall, S. (2001). Competitiveness Indices and Developing Countries: An Economic Evaluation of the Global Competitiveness Report. World Development, 29(9). http://dx.doi.org/10.1016/S0305-750X(01)00051-1.

Lopez-Claros, A., Altinger, L., Blanke, J., Drzeniek, M. \& Mia, I. (2006). The Global Competitiveness Index: Identifying the Key Elements of Sustainable Growth. The Global Competitiveness Report 2006-2007, World Economic Forum, Palgrave Macmillan.

Lucas, R. (1988). On the Mechanics of Economic Development. Journal of Monetary Economics, 22(1). http://dx.doi.org/10.1016/0304-3932(88)90168-7.

Nair-Reichert, U. \& Weinhold, D. (2001). Causality Tests for Cross-Country Panels: A New Look at FDI and Economic Growth in Developing Countries. $O x$ ford Bulletin of Economics and Statistics, 63(2). http://dx.doi.org/10.1111 11468-0084.00214.

Olczyk, M. (2008). Konkurencyjność - Teoria i praktyka. Warszawa: Wydawnictwo Fachowe CEDEWU. 
Pagano, M. (1993). Financial Markets and Growth: an Overview. European Economic Review, 37(2-3). http://dx.doi.org/10.1016/0014-2921(93)90051-B.

Porter, M. E. (1990). The competitive advantage of nations. London: Macmillan.

Qin, H., Prybutok, V. R., \& Peak, D. A. (2009). Service Quality in the USA and mainland China's fast-food restaurants. International Journal of Services and Standards, 5(4). http://dx.doi.org/10.1504/IJSS.2009.032174.

Romer, M. P. (1986). Increasing Returns and Long-Run Growth. The Journal of Political Economy, 94(5). http://dx.doi.org/10.1086/261420.

Romer, P. (1990). Endogenous Technological Change. Journal of Political Economy, 98(S5) http://dx.doi.org/10.1086/261725.

Rugman, A. M. (1990). Global Corporate Strategy and Trade Policy. London and New York: Routledge.

Rugman, A. M. (1991). Diamond in the Rough. Business Quarterly, 55(3).

Rugman, A. M. \& D'Cruz, J. R. (1993). The 'Double Diamond' Model of International Competitiveness: the Canadian Experience. Management International Review, Special Issue, 33.

Schwab, K. (2015). The Global Competitiveness Report 2014-2015. Retrieved from http://www.weforum.org. (28.02.2015).

Smit, A. J. (2010). The Competitive Advantage of Nations: Is Porter's Diamond Framework a New Theory that Explains the International Competitiveness of Countries? Southern African Business Review, 14 (1).

Stel, A. van, Carree, M. \& Thurik, A. R. (2005). The Effect of Entrepreneurial Activity on National Economic Growth. Small Business Economics, 24(3). http://dx.doi.org/10.1007/s11187-005-1996-6.

Waverman, L. (1995). A Critical Analysis of Porter's Framework on the Competitive Advantage of Nations. In A. Rugman, Van den Broeck, J. \& Verbeke, A. (Eds.), Research in Global Strategic Management: Volume V. Beyond the Diamond. Greenwich, CT: JAI Press.

Weinhold, D. (1996). Investment, Growth and Causality Testing in Panels. Economie et Prevision, 126.

Weinhold, D. (1999). A Dynamic 'Fixed Effects' Model for Heterogeneous Panel Data. Unpublished manuscript, London School of Economics.

World Bank, (2015). Data indicator: GDP, PPP (current international \$). Retrieved from http://data.worldbank.org/indicator/NY.GDP.MKTP.PP.CD (01.03.2015).

Xia, R., Liang, T., Zhang, Y. \& Wu, S. (2012). Is Global Competitive Index a Good Standard to Measure Economic Growth? A Suggestion for Improvement. International Journal of Services and Standards, 8(1). http://dx.doi.org/10.1504/IJSS.2012.048438. 